\title{
Preparation of potassium nitrate from potassium chloride and magnesium nitrate in a laboratory scale using industrial raw materials
}

\author{
Jana Jurišováa ${ }^{a}$ Pavel Fellner ${ }^{a}$, Vladimír Danielik ${ }^{a}$, \\ Marek Lencsés ${ }^{\mathrm{b}}$, Milan Králik ${ }^{\mathrm{b}}$, Rastislav Šípoša \\ ${ }^{a}$ Institute of Inorganic Chemistry, Technology and Materials, \\ Faculty of Chemical and Food Technology STU in Bratislava, \\ Radlinského 9, 81237 Bratislava, Slovak Republic \\ ${ }^{b}$ VUCHT, a.s., Nobelova 34, 83603 Bratislava, Slovak Republic \\ jana.jurisova@stuba.sk
}

\begin{abstract}
Preparation of potassium nitrate from magnesium nitrate and potassium chloride was investigated. Prepared potassium nitrate contains less than $0.5 \%$ chlorides and it can be applied as environmentally friendly fertilizer in hydroponic systems. After filtration out potassium nitrate crystals from the reciprocal system $\mathrm{K}^{+}, \mathrm{Mg}^{2+} / / \mathrm{Cl}^{-}, \mathrm{NO}_{3}^{-}-\mathrm{H}_{2} \mathrm{O}$, the mother liquor still contains reasonable amount of potassium cations. By evaporation of the mother liquor, carnallite $\left(\mathrm{MgCl}_{2} \cdot \mathrm{KCl} \cdot 6 \mathrm{H}_{2} \mathrm{O}\right)$ with admixture of $\mathrm{MgCl}_{2} \cdot 6 \mathrm{H}_{2} \mathrm{O}$ crystallizes out. Decomposition of carnallite with cold water makes it possible to separate potassium chloride from this compound. When this $\mathrm{KCl}$ is returned back to the process of $\mathrm{KNO}_{3}$ making, utilization of potassium as high as $97 \%$ can be achieved.
\end{abstract}

Keywords: potassium nitrate, magnesium nitrate, carnallite

\section{Introduction}

Pure chemicals and their mixtures are increasingly applied in environmentally friendly plant growing, especially in irrigation and hydroponic systems. Pure magnesium nitrate, calcium nitrate and potassium nitrate represent important components used for these purposes.

Depending on available raw materials, different methods for production of $\mathrm{KNO}_{3}$ have been proposed. Some of them were actualized in industrial measure. For example, $\mathrm{KCl}$ reacts with $\mathrm{HNO}_{3}$ at the temperature of $75{ }^{\circ} \mathrm{C}$ according to the following reaction scheme (Phosphorus and Potassium 1965):

$3 \mathrm{KCl}+4 \mathrm{HNO}_{3}=3 \mathrm{KNO}_{3}+\mathrm{Cl}_{2}+\mathrm{NOCl}+2 \mathrm{H}_{2} \mathrm{O}(1)$

In the next step, $\mathrm{NOCl}$ is oxidized with nitric acid at $150{ }^{\circ} \mathrm{C}$

$$
2 \mathrm{NOCl}+4 \mathrm{HNO}_{3}=\mathrm{Cl}_{2}+6 \mathrm{NO}_{2}+2 \mathrm{H}_{2} \mathrm{O}
$$

$\mathrm{NO}_{2}$ is oxidized and used again for the production of nitric acid and chlorine can be used for another purpose. To avoid corrosion problems and oxidation of NOCl the company Israel Mining Industries carries out the reaction between $\mathrm{KCl}$ and $\mathrm{HNO}_{3}$ at low temperatures:

$$
\mathrm{KCl}+\mathrm{HNO}_{3}=\mathrm{KNO}_{3}+\mathrm{HCl}
$$

In this case $\mathrm{HCl}$ has to be removed from the reaction mixture, which is done with organic solvent (Phosphorus and Potassium 1969).
Several methods based on the conversion of $\mathrm{KCl}$ with another nitrates were studied. Some of them were carried out in industrial measure. General reaction scheme is as follows:

$$
\begin{gathered}
\mathrm{K}^{+}(\mathrm{aq})+\mathrm{Cl}^{-}(\mathrm{aq})+\mathrm{M}^{+}(\mathrm{aq})+\mathrm{NO}_{3}^{-}(\mathrm{aq})= \\
=\mathrm{M}^{+}(\mathrm{aq})+\mathrm{Cl}^{-}(\mathrm{aq})+\mathrm{KNO}_{3}(\mathrm{~s})
\end{gathered}
$$

where $\mathrm{M}^{+}$can be $\mathrm{Na}^{+}, \mathrm{Ca}^{2+}$, or as in the case discussed in this paper $\mathrm{Mg}^{2+}$.

When $\mathrm{K}_{2} \mathrm{SO}_{4}$ is used instead of $\mathrm{KCl}$ as source of potassium, $\mathrm{KNO}_{3}$ can be prepared by the reaction

$$
\mathrm{K}_{2} \mathrm{SO}_{4}+\mathrm{Ca}\left(\mathrm{NO}_{3}\right)_{2}=2 \mathrm{KNO}_{3}+\mathrm{CaSO}_{4}
$$

Each of these methods has advantages and disadvantages, the main problems being purity of prepared $\mathrm{KNO}_{3}$, treatment of wastes and, of course, price of the used technology.

In this work we will discuss in detail the conversion of $\mathrm{KCl}$ with $\mathrm{Mg}\left(\mathrm{NO}_{3}\right)_{2}$ :

$$
2 \mathrm{KCl}+\mathrm{Mg}\left(\mathrm{NO}_{3}\right)_{2}=2 \mathrm{KNO}_{3}+\mathrm{MgCl}_{2}
$$

Patent literature describes preparation of starting solutions for crystallization of $\mathrm{KNO}_{3}$ (Germany Patent 374.095 (1923); 365.587 (1923); 374.096 (1923); 394.464 (1924); 399.465 (1924); 401.979 (1924); 403.996 (1924); 403.997 (1924)) and the conditions for removing $\mathrm{MgCl}_{2}$ from the solution, usually as carnallite, $\mathrm{KCl} \cdot \mathrm{MgCl}_{2} \cdot 6 \mathrm{H}_{2} \mathrm{O}$ (Germany Patent 414.597 (1927); 413.300 (1925); 413.299 (1925); 405.579 (1924)). It would be of great advantage if 
potassium from carnallite could also be used for preparation of $\mathrm{KNO}_{3}$. This would substantially increase utilization of potassium which is valuable constituent of fertilizers.

For quantitative evaluation of reaction (6), reliable equilibrium data for the reciprocal system $\mathrm{K}^{+}$, $\mathrm{Mg}^{2+} / / \mathrm{Cl}^{-}, \mathrm{NO}_{3}^{-}-\mathrm{H}_{2} \mathrm{O}$ are needed. Phase diagram of the system $\mathrm{K}^{+}, \mathrm{Mg}^{2+} / / \mathrm{Cl}^{-}, \mathrm{NO}_{3}^{-}-\mathrm{H}_{2} \mathrm{O}$ for the temperature of $5^{\circ} \mathrm{C}$ was published by Žúžiová et al. 1988. Matveeva and Kudryashova 2009 studied this system at $25^{\circ} \mathrm{C}$ and $50^{\circ} \mathrm{C}$. Equilibrium data at $20^{\circ} \mathrm{C}$, $40{ }^{\circ} \mathrm{C}$ and $60^{\circ} \mathrm{C}$ are available only in an internal report (VÚAgT 1973). For illustration phase diagram of the reciprocal system $\mathrm{K}^{+}, \mathrm{Mg}^{2+} / / \mathrm{Cl}^{-}, \mathrm{NO}_{3}^{-}-\mathrm{H}_{2} \mathrm{O}$ obtained at the temperature of $20{ }^{\circ} \mathrm{C}$ is presented in Fig. 1 (VÚAgT 1973). (Potassium chloride is denoted as $\mathrm{K}_{2} \mathrm{Cl}_{2}$ because of charge equality of two potassium cations with $\mathrm{Mg}^{2+}$ cation. This formalism makes the phase diagram more symmetric.)

For industrial application the phase equilibria at higher temperatures up to $90{ }^{\circ} \mathrm{C}$ are desirable. Prediction of equilibria at higher temperatures could limit a number of necessary experimental measurements. For the purpose of $\mathrm{KNO}_{3}$ production, only the section $\mathrm{MgCl}_{2}-\mathrm{KNO}_{3}$ were thermodynamically treated for consistency and prediction. This topic will be discussed in detail in paper (Danielik et al. to be published). In this paper we will present the results obtained at preparation of potassium nitrate in laboratory scale from raw materials that are expected to be used in industry. Purity of final prod- uct $\left(\mathrm{KNO}_{3}\right)$, especially the content of chlorides, is of primary importance. Thus the influence of rate of crystallization, washing of crystals, etc. is discussed in detail.

\section{Experimental}

\section{Chemicals used}

As has been mentioned in the introduction, industrial raw materials were used for preparation of $\mathrm{KNO}_{3}$. KCl (supplier: Kalij - White Russia) has following composition (wt. \%):

$\mathrm{KCl}-94.6 \% ; \mathrm{MgCl}_{2}-1.2 \% ; \mathrm{NaCl}-1.8 \%$; $\mathrm{CaCl}_{2}-0.4 \%$; sand $2 \%$.

Composition of magnesite (supplier SMZ Jelšava, Slovakia) is as follows (wt. \%):

$\mathrm{MgCO}_{3}-85.7 \% ; \mathrm{CaCO}_{3}-7.20 \% ; \mathrm{FeCO}_{3}-4.36$; $\mathrm{SiO}_{2}-1.93 \% ; \mathrm{MnCO}_{3}-0.11 \%$; moisture $0.7 \%$.

\section{Preparation of $\mathrm{Mg}\left(\mathrm{NO}_{3}\right)_{2}$ solution}

$2 \mathrm{~kg}$ of raw magnesium carbonate (diameter from 50 to $90 \%$ of particles is in the range $0.063-0.250 \mathrm{~mm}$ ) is added under mixing to $5 \mathrm{~kg}$ of nitric acid (60\%) until concentration of the nitric acid drops to $2-4 \%$. Because of reaction heat, temperature of the solution increases from ca $30^{\circ} \mathrm{C}$ up to ca $110^{\circ} \mathrm{C}$. Rate of addition of magnesite is determined by foam formation. Rest of the acid is neutralized by the addition of $\mathrm{MgO}$ powder until $\mathrm{pH}$ of the solution reaches 6.6-7.0. This solution is diluted by distilled water and filtered at the temperature of $50-80^{\circ} \mathrm{C}$.

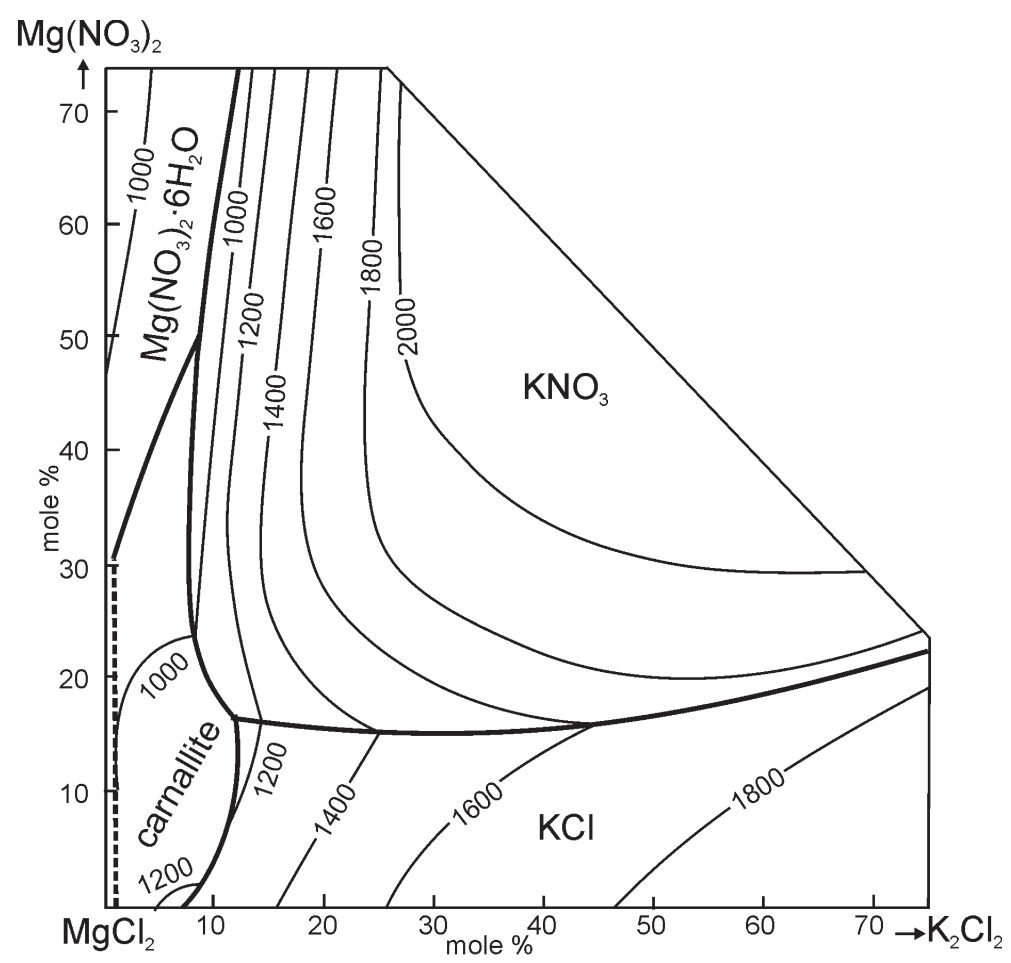

Fig. 1. Phase diagram of the system $\mathrm{K}^{+}, \mathrm{Mg}^{2+} / / \mathrm{Cl}^{-}, \mathrm{NO}_{3}^{-}-\mathrm{H}_{2} \mathrm{O}$ at the temperature of $20{ }^{\circ} \mathrm{C}$ with the areas of crystallization of components (VÚAgT 1973). 
Analysis of raw materials and of $\mathrm{KNO}_{3}$

Magnesium and calcium are determined by complexometric titration with aqueous solution of sodium salt of EDTA at $\mathrm{pH}=10$. Erichrome black $\mathrm{T}$ is used as indicator.

Determination of $\mathrm{NO}_{3}^{-}$. Nitrate anion oxidizes $\mathrm{FeSO}_{4}$ in the presence of $\mathrm{H}_{2} \mathrm{SO}_{4}$ at elevated temperature to $\mathrm{Fe}_{2}\left(\mathrm{SO}_{4}\right)_{3}$. Surplus of $\mathrm{FeSO}_{4}$ is titrated with $0.05 \mathrm{M}$ $\mathrm{KMnO}_{4}$ solution.

Chloride anions were determined either by ion chromatography or by argentometry.

\section{Preparation of $\mathrm{KNO}_{3}$}

Mother liquor for crystallization of $\mathrm{KNO}_{3}$ was prepared in the following way. $350 \mathrm{~g}$ of $\mathrm{Mg}\left(\mathrm{NO}_{3}\right)_{2}$ solution (40.7 wt. \% $\left.\mathrm{Mg}\left(\mathrm{NO}_{3}\right)_{2}\right)$ was mixed with $158 \mathrm{~g}$ of $\mathrm{KCl}$ (technical grade) and $148 \mathrm{~g}$ of deionized water in $1000 \mathrm{ml}$ beaker. The beaker was covered with a lid to prevent evaporation. The mixture was heated up to $96{ }^{\circ} \mathrm{C}$. When salts were dissolved, solid impurities originating from $\mathrm{KCl}$ were filtered out at the temperature higher that $90{ }^{\circ} \mathrm{C}$ in order to prevent crystallization of potassium nitrate. Mass of solid impurities was ca $2 \mathrm{~g}$. Then the solution was cooled to $10^{\circ} \mathrm{C}$. The amount of $\mathrm{KNO}_{3}$ crystals obtained by filtration from this solution was washed with $171 \mathrm{~g}$ of deionized water. Temperature of washing deionized water was also $10{ }^{\circ} \mathrm{C}$. Washing of $\mathrm{KNO}_{3}$ crystals was carried out in a closed vessel which made it possible to use intensive mixing. The crystals of $\mathrm{KNO}_{3}$ were filtered out and dried at $60{ }^{\circ} \mathrm{C}$.
Solution remaining after washing of $\mathrm{KNO}_{3}$ crystals (ca $210 \mathrm{~g}$ ) was used in the next experiment for preparation of the reaction mixture instead of water. Mother liquor remaining after filtration of $\mathrm{KNO}_{3}$ was concentrated by evaporation of water. The amount of evaporated water was that required for washing of $\mathrm{KNO}_{3}$ crystals (and required in the next step for preparation of the solution (see Fig. 2).

Scheme for preparation of $\mathrm{KNO}_{3}$ with proposed recycling streams is depicted in Fig. 2.

$\mathrm{KNO}_{3}$ crystals were characterized also by SEM (Tesla BS 300 equipped with digital unit Tescan).

\section{Results and Discussion}

Maximal yield of potassium nitrate can be estimated on the basis of phase diagram of the reciprocal system $\mathrm{K}^{+}, \mathrm{Mg}^{2+} / / \mathrm{Cl}^{-}, \mathrm{NO}_{3}{ }^{-}-\mathrm{H}_{2} \mathrm{O}$. It follows that maximum utilization of potassium chloride can be $86.6 \%$. This yield is achieved when the saturated mother liquor is prepared from pure $\mathrm{Mg}\left(\mathrm{NO}_{3}\right)_{2}$ and $\mathrm{KCl}$ and the solution is cooled to $10^{\circ} \mathrm{C}$. Of course, when raw materials containing impurities are used, this has to be taken into account.

Crucial requirement on prepared potassium nitrate is its purity. The amount of chlorides should not exceed ca 0.5 wt. \%. Purity of $\mathrm{KNO}_{3}$ crystals is influenced not only by the presence of impurities in the solution but also by washing of the crystals. It depends also on the kinetics of crystal growth which can be influenced by the rate of cooling and by mixing of the mother solution.

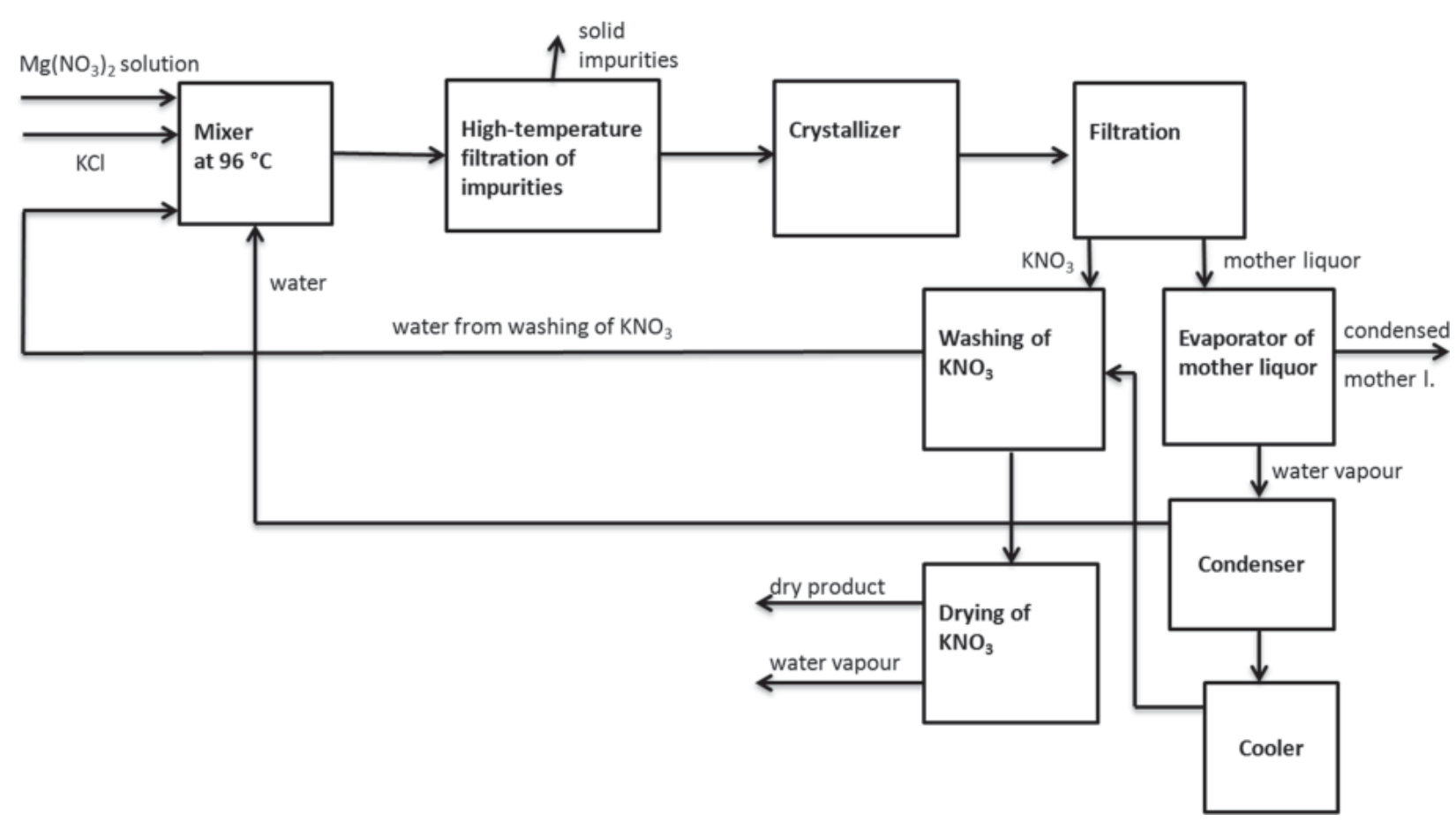

Fig. 2. Scheme of production of $\mathrm{KNO}_{3}$ by conversion reaction of $\mathrm{KCl}$ and $\mathrm{Mg}\left(\mathrm{NO}_{3}\right)_{2}$. 
Two series of experiments were carried out:

A. Crystallization of $\mathrm{KNO}_{3}$ without mixing of the mother liquor

B. Crystallization with mixing

\section{Series A}

In this series of experiments, crystallization of $\mathrm{KNO}_{3}$ proceeded without mixing. After removal of solid impurities by filtering, the beaker containing saturated solution was cooled down in the mixture of water with ice. When the temperature of the solution reached $10{ }^{\circ} \mathrm{C}, \mathrm{KNO}_{3}$ crystals were filtered out using a Büchner funnel. The results are summarized in Table 1.

\section{Series $B$}

In this series, the preparation of $\mathrm{KNO}_{3}$ was carried out in a similar way as in series A. The only difference was in cooling which was now carried out under mixing by an impeller stirrer. All data related to these experiments are summarized in Table 2. It can be seen that we could obtain product with content of chlorides as low as $0.2 \%$ at high yield ( $84 \%$ ) of potassium nitrate. Crystals of $\mathrm{KNO}_{3}$ obtained in this way are smaller and more homogeneous as the crystals obtained without mixing. Appearance of the crystals can be seen on Fig. 3 .

\section{Decomposition of carnallite}

When solid potassium nitrate is removed from the system, the solution still contains reasonable amount of potassium ions. By evaporation of water from this solution (this water is returned back to the process) we obtain after cooling to $25^{\circ} \mathrm{C}$ solid phase consisting of carnallite $\left(\mathrm{KCl} \cdot \mathrm{MgCl}_{2} \cdot 6 \mathrm{H}_{2} \mathrm{O}\right), \mathrm{KNO}_{3}$, and small amount of $\mathrm{MgCl}_{2} \cdot 6 \mathrm{H}_{2} \mathrm{O}$. In the next we will denote this mixture of crystals as "raw carnallite”. Carnallite makes $94 \%$ of the solid phase, i.e. of "raw carnallite". Decomposition of this material (this is also known as "processing of carnallite") yields solid $\mathrm{KCl}$ and solution containing $\mathrm{MgCl}_{2}$ and $\mathrm{KCl}$ (and small amount of nitrates). This is a well established process (see for example Ullmann's encyclopedia of Industrial Chemistry).

The process of decomposition of "raw carnallite" is illustrated in Fig. 4. Result of our experiments is as follows. When we added $42.5 \mathrm{ml}$ of distilled water to $100 \mathrm{~g}$ of "raw carnallite" we obtained $19.7 \mathrm{~g}$ of $\mathrm{KCl}$ which is returned back to the process of preparation of $\mathrm{KNO}_{3}$. Using this procedure, utilization of potassium from KCl for $\mathrm{KNO}_{3}$ production increases up to $97 \%$. Work on the treatment of the residual solid phase containing ca $25 \%$ of carnallite and ca $74 \%$ of $\mathrm{MgCl}_{2} \cdot 6 \mathrm{H}_{2} \mathrm{O}$ (the rest being nitrates) is under progress.

\section{Acknowledgment}

This work was supported by the Slovak Research and Development Agency under the contract No. APVV-0387-10.

\section{References}

Danielik V, Jurišová $\mathrm{J}$ and Fellner $\mathrm{P}$ to be published in Chemical Papers.

Tab. 1. Summary of results, series A.

\begin{tabular}{|c|c|c|c|c|}
\hline No. & 1 & 2 & 3 & 4 \\
\hline \multirow{3}{*}{ Weighed-in } & $158 \mathrm{~g} \mathrm{KCl}$ & $158 \mathrm{~g} \mathrm{KCl}$ & $158 \mathrm{~g} \mathrm{KCl}$ & $158 \mathrm{~g} \mathrm{KCl}$ \\
\hline & $\begin{array}{l}350 \mathrm{~g} \mathrm{Mg}\left(\mathrm{NO}_{3}\right)_{2} \\
\text { solution }\end{array}$ & $\begin{array}{l}350 \mathrm{~g} \mathrm{Mg}\left(\mathrm{NO}_{3}\right)_{2} \\
\text { solution }\end{array}$ & $\begin{array}{l}350 \mathrm{~g} \mathrm{Mg}\left(\mathrm{NO}_{3}\right)_{2} \\
\text { solution }\end{array}$ & $\begin{array}{l}350 \mathrm{~g} \mathrm{Mg}\left(\mathrm{NO}_{3}\right)_{2} \\
\text { solution }\end{array}$ \\
\hline & $148 \mathrm{~g}$ deion. water & $\begin{array}{l}203 \mathrm{~g} \text { of washing } \\
\text { solution from No.1. }\end{array}$ & $\begin{array}{c}208 \mathrm{~g} \text { washing } \\
\text { solution from No. } 2 .\end{array}$ & $\begin{array}{l}209 \mathrm{~g} \text { washing } \\
\text { solution from No. } 3\end{array}$ \\
\hline Solid impurities & $1.66 \mathrm{~g}$ & $1.13 \mathrm{~g}$ & $2.48 \mathrm{~g}$ & $1.92 \mathrm{~g}$ \\
\hline Mass of dry $\mathrm{KNO}_{3}$ & $144 \mathrm{~g}$ & $169 \mathrm{~g}$ & $167 \mathrm{~g}$ & $167 \mathrm{~g}$ \\
\hline Content of chlorides, wt. \% & 0.49 & 0.57 & 0.62 & 0.61 \\
\hline
\end{tabular}

Tab. 2. Summary of results, series B.

\begin{tabular}{lccc}
\hline No. & $\mathbf{1}$ & $\mathbf{2}$ & $\mathbf{3}$ \\
\hline & $158 \mathrm{~g} \mathrm{KCl}$ & $158 \mathrm{~g} \mathrm{KCl}$ & $158 \mathrm{~g} \mathrm{KCl}$ \\
Weighed-in & $350 \mathrm{~g} \mathrm{Mg}\left(\mathrm{NO}_{3}\right)_{2}$ solution & $\begin{array}{c}350 \mathrm{~g} \mathrm{Mg}\left(\mathrm{NO}_{3}\right)_{2} \text { solution } \\
209 \mathrm{~g} \text { washing solution } \\
\text { from No. }\end{array}$ & $\begin{array}{c}350 \mathrm{~g} \mathrm{Mg}\left(\mathrm{NO}_{3}\right)_{2} \text { solution } \\
214 \mathrm{~g} \text { washing solution } \\
\text { from No. } 2\end{array}$ \\
\hline Impurities & $148 \mathrm{~g}$ water & $0.64 \mathrm{~g}$ & $1.72 \mathrm{~g}$ \\
\hline Mass of dry $\mathrm{KNO}_{3}$ & $3.18 \mathrm{~g}$ & $157 \mathrm{~g}$ & 159 \\
\hline Content of chlorides, wt. $\%$ & $133 \mathrm{~g}$ & 0.23 & 0.20 \\
\hline
\end{tabular}




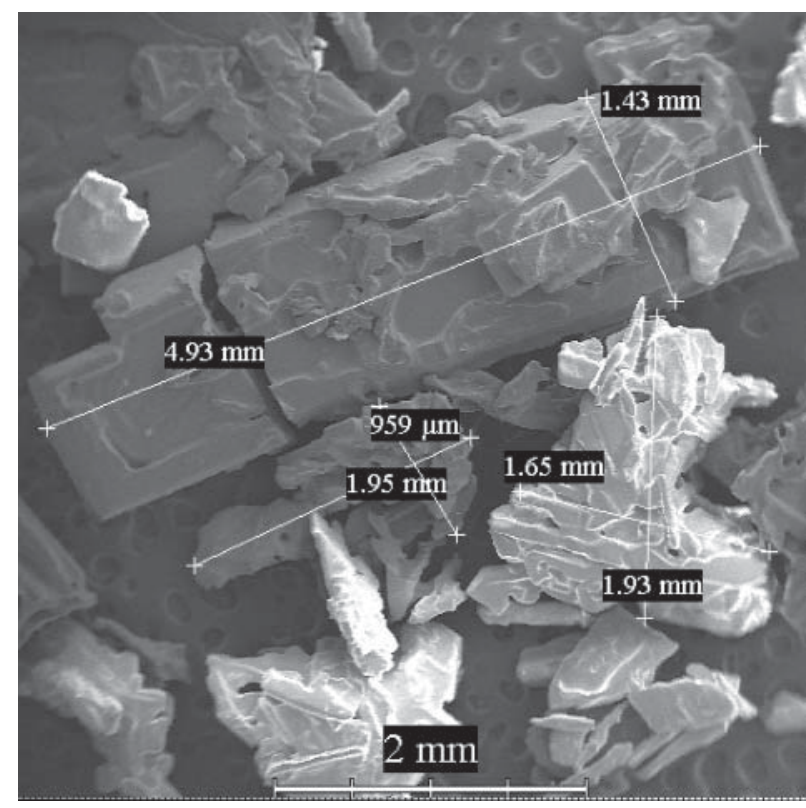

A.

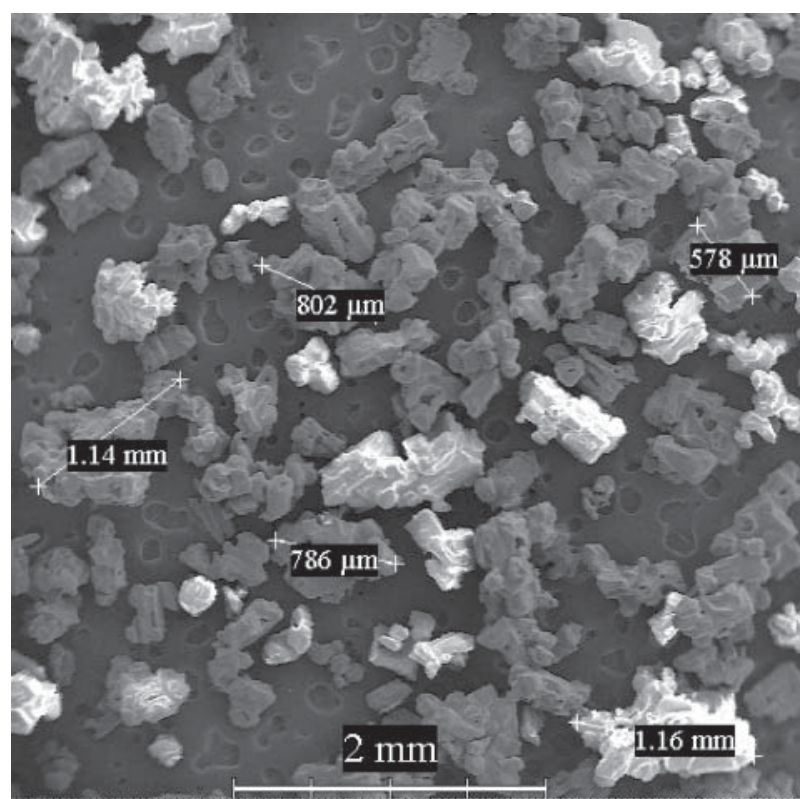

B.

Fig. 3. Pictures of crystals of potassium nitrate obtained in series A and B, respectively.

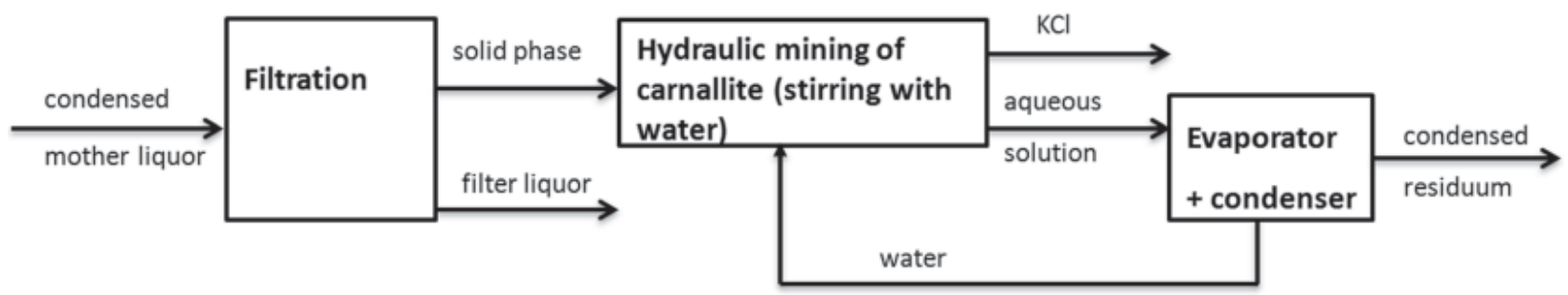

Fig. 4. Scheme of processing of the secondary product (condensed mother liquor) from the evaporator (see also Fig. 1).

Germany Patent 374.095 (1923). Germany Patent 365.587 (1923). Germany Patent 374.096 (1923). Germany Patent 394.464 (1924). Germany Patent 399.465 (1924). Germany Patent 401.979 (1924). Germany Patent 403.996 (1924). Germany Patent 403.997 (1924). Germany Patent 414.597 (1927). Germany Patent 413.300 (1925). Germany Patent 413.299 (1925). Germany Patent 405.579 (1924).
Internal report VÚAgT (1973) Bratislava.

Matveeva KR, Kudryashova OS (2009) Russian Journal of Inorganic Chemistry 54 (12) 2079-2082.

Phosphorus and Potassium (1965) 19, 31.

Phosphorus and Potassium (1969) 41, 40.

Ullmann's encyclopedia of Industrial Chemistry, Potassium Compounds, Wiley-VCH Verlag $\mathrm{GmbH}$ \& Co. KGaA, Weinheim, p. 22, 2005, DOI: 10.1002/14356007.a22 039.

Žúžiová A, Khandl V, Plančík M (1988) Chemický průmysl 38/63 (12) 643-646. 